\title{
Fabio Weintraub
}

\section{Como você pensa a relação entre o tempo literá- rio e o tempo histórico?}

Penso a relação entre esses tempos de modo não especular, na contramão dos que querem converter a literatura em epifenômeno histórico. A obra literária se plasma na intersecção de múltiplas temporalidades; o que não implica necessariamente adesão às leituras sincrônicas ou de tipo retórico.

Se ela é historiografia inconsciente, para lembrar a lição de Adorno, cumpre verificar de que modo, em cada caso, a história do sujeito vai sendo apreendida e cifrada no encontro entre moções psíquicas, valores ideológicos e modelos de desempenho formal, entre outros aspectos.

\section{Quais procedimentos sua obra adota diante de um mundo em que predominam a ação econô- mica e a espetacularização da arte?}

A pergunta pode ensejar uma compreensão programática da literatura com a qual não me identifico. Acho que uma das formas de resistir à espetacularização e à mercadorização da arte é justamente não ceder aos apelos da arte-denúncia, não vestir a carapuça do vate paladino que se julga a salvo da barbárie, como ocorre em obras com pretensão documental, que apenas mimetizam os aspectos mais degradantes e brutais do mundo contemporâneo sem deslocamentos significativos; ou que forjam uma versão estetizada desses aspectos, em sintonia com as demandas de consumo.

No que me diz respeito, tenho me dedicado nos últimos anos à investigação da sociabilidade conflitiva que distingue a vida nos grandes centros urbanos, buscando entendê-la por meio de cisões da voz lírica.
Qual reflexão sua obra produz sobre a tradição literária brasileira?

Julgo que o trabalho que venho realizando desde Novo endereço (2002) é movido pelo desejo de transitar entre modos de expressão oriundos de diferentes classes sociais, misturando linguagens, contrapondo perspectivas, trazendo para o registro lírico recursos narrativos e dramáticos. Sinto-me próximo, nesse sentido, dos caminhos percorridos por um Chico Alvim, sem no entanto partilhar com ele a tendência ao miniaturismo.

Penso que o desafio com que se deparam aqueles que tencionam seguir nessa trilha é o de não ficcionalizar autoritariamente a voz do outro em função de qualquer voluntarismo político. $\mathrm{Ou}$, dito de outro modo, o desafio é o de mediar subjetivamente essa "captação de dizeres" (que deve ser mimética e contraditória, ou seja, reflexiva não somente em termos ópticos) sem transformar a "cessão de voz" em imposição falsificadora.

\section{Como você pensa a forma literária?}

Difícil responder abstratamente, mas me arrisco a pensar a forma literária como um compromisso entre fatores de natureza vária: exigências da matéria a ser representada, circunstâncias histórico-sociais, preceptivas com que o artista se alinha, interferências fortuitas, intuições e assim por diante. Quando o artista não opera no piloto automático, quando não cede à autoimitação tornando-se refém de um estilo, a forma me parece sempre uma resposta provisória às perguntas do mundo.

Fabio Weintraub (1967) é poeta, editor e autor de Toda mudez será conquistada (Massao Ohno Editor, 1992), Sistema de anos (Arte Pau-Brasil, 1996), Novo endereço (Nankin/ Funalfa, 2002) e Baque (Editora 34, 2007). 